\title{
O CUIDADO DE SI COMO PRÁTICA DE LIBERDADE NUMA PENITENCIÁRIA FEMININA DO ESTADO DE SÃO PAULO
}

\author{
Caroline D.A. Mello*, Ariane G. Rios, Sílvia M. Santiago
}

\section{Resumo}

Desde o século $V$ a.c. os gregos reconheciam a importância do cuidado de si. Entendendo que, a partir do desenvolvimento de técnicas do cuidado de si, o sujeito pode avançar para práticas de liberdade que auxiliam no convívio no cárcere e nas relações sociais futuras, quando em liberdade, a pesquisa objetivou conhecer o perfil das mulheres privadas de liberdade no Brasil e numa penitenciária feminina do Estado de São Paulo. Ainda, conhecer as práticas de cuidado de si de forma a compreender as melhores estratégias educativas que sejam libertadoras, visando o futuro em suas comunidades. Trata-se de estudo qualitativo, de inspiração cartográfica no que se refere à presença do pesquisador no campo de forma a partilhar a construção da pesquisa com as reeducandas.

\section{Palavras-chave:}

encarceramento, mulheres, auto cuidado.

\section{Introdução}

Atualmente, no Brasil e no mundo, uma das maiores chagas sociais é o crescente encarceramento da população pobre, em geral jovem e, em alguns países, oriundos da raça negra. No nosso país acrescenta-se a esta tragédia o encarceramento feminino, que cresce a taxas superiores a dos homens, apesar de ainda ser uma população bem menor em números absolutos. A grande maioria dessas mulheres tem filhos e muitos ficam ao desamparo durante o encarceramento . A maioria das detentas são pobres, com baixa escolaridade e negras, além da taxa de reincidência no crime ser alta. $O$ cuidado de si, nas suas várias dimensões, física, psíquica e espiritual, pode ser ferramenta para o auto-conhecimento, melhoria das condições de saúde e emponderamento para serem resilientes no cárcere e após o encarceramento, seja uma prática de liberdade. Objetivou-se conhecer e avaliar o recorte social e as práticas de cuidado de si dessas mulheres, de forma a que ações educativas sejam mais focadas e significativas para elas.

\section{Resultados e Discussão}

A partir de uma pesquisa qualitativa, de ethos cartográfico, detentas de uma penitenciária feminina do estado de São Paulo serão abordadas para relatarem sua experiência com o Cuidado de Si. Serão consideradas as dimensões estéticas, físicas, psíquica/emocional,intelectual, espiritual e do âmbito do feminino. Foram levantados dados relevantes para melhor compreender o perfil das mulheres encarceradas no Brasil ( $n$ variável para cada quesito) e na penitenciária feminina de Campinas ( $\mathrm{n}$ fixo, 1013 mulheres entrevistadas em projeto já realizado), com suas semelhanças e peculiaridades. Assim como nacionalmente, $50 \%$ das detentas possuem entre 18 e 29 anos, na instituição em questão, $82 \%$ têm até 39 anos, mostrando uma população carcerária majoritariamente jovem. Sobre a questão étnico racial, no Brasil, $62 \%$ da população carcerária é negra, sendo essa diferença pouco menor localmente, com $51,7 \%$ de presas não brancas. Dados nacionais de 2018 mostram que 45\% das mulheres possuem ensino fundamental incompleto e apenas $15 \%$ concluiram o ensino médio, taxas próximas da população alvo do projeto, que mostra 33,2\% com ensino fundamental incompleto e a maioria, $63 \%$, ter somente de 0 a 3 anos de estudo. No âmbito nacional e local, respectivamente, $62 \%$ e $51 \%$ são solteiras, a grande maioria destas mulheres são mães (74 e 80,6\% respectivamente), apontando para o provável impacto do encarceramento nas famílias e na sociedade. Neste sentido mostra-se relevante a implantação de mais unidades prisionais com berçários e creches, já que apenas $14 \%$ das unidades possuem berçários para crianças até 2 anos e $3 \%$ creches para os acima desta idade.

\section{Conclusões}

A pesquisa mostrou que a população prisional feminina brasileira é composta principalmente por mulheres jovens, mães, negras e de baixa escolaridade. Este panorama funcionará como embasamento para as análises das narrativas e entrevistas das detentas e, assim, melhor formulação das atividades em promoção de saúde destinadas a elas. Para a realização deste componente do projeto, já temos a aprovação do Comitê de Ética e Pesquisa da UNICAMP, CAE n 11741719.3.0000.5404, mas ainda há a exigência da aprovação do CEP SAP (Secretaria da Administração Penitenciária), o qual ainda estamos aguardando, visto que, por um erro não identificado, este projeto fora enviado a outro estado. Em breve deveremos iniciar esta relevante segunda parte da pesquisa.

\section{Agradecimentos}

À UNICAMP, CNPq/PIBIC e Penitenciária Feminina de Campinas por todo o apoio. Às mulheres encarceradas nosso agradecimento e respeito

AUDI, C.A.F. et al. Inquérito sobre condições de saúde de mulheres encarceradas. Saúde Debate v.40, n.109. Rio de Janeiro: ABR-JUN 2016. FOUCAULT, M. A ética do cuidado de si como prática da liberdade. In: Ditos \& Escritos V - Ética, Sexualidade, Política. Rio de Janeiro: Forense Universitária, 2004.

THANDARA, S. et al. Levantamento nacional de informações penitenciárias INFOPEN Mulheres - $2^{\text {a }}$ Edição. Brasília, DF: Ministério da Justiça e Segurança Pública. Departamento Penitenciário Nacional, 2017. 